\title{
Primary Congenital Glaucoma 3A
}

National Cancer Institute

\section{Source}

National Cancer Institute. Primary Congenital Glaucoma 3A. NCI Thesaurus. Code C148260.

An autosomal recessive form of congenital glaucoma caused by mutation(s) in the CYP1B1 gene, encoding cytochrome P450 1B1. 